\title{
Cbl-regulated Akt and ERK signals are involved in $\beta$-elemene-induced cell apoptosis in lung cancer cells
}

\author{
LEI LI ${ }^{1 *}$, LING XU ${ }^{2 *}$, XIUJUAN QU ${ }^{2}$, MINGFANG ZHAO ${ }^{2}$, \\ PING YU ${ }^{2}$, JIAN KANG ${ }^{1}$, YUNPENG LIU ${ }^{2}$ and XUEJUN HU ${ }^{1}$ \\ Departments of ${ }^{1}$ Respiratory Medicine, and ${ }^{2}$ Medical Oncology, \\ The First Hospital of China Medical University, Shenyang 110001, P.R. China
}

Received April 27, 2011; Accepted August 8, 2011

DOI: $10.3892 / \mathrm{mmr} .2011 .548$

\begin{abstract}
. $\beta$-elemene is an active component of a natural plantderived antineoplastic agent. Although the anticancer activity of $\beta$-elemene has been reported, its antitumor mechanism has not been elucidated. The aim of the present study was to investigate how Cbl-regulated Akt and ERK affect $\beta$-elemeneinduced cell apoptosis in lung cancer cells. In the present study, $\beta$-elemene induced cell apoptosis in a dose-dependent manner in A549 cells. Moreover, $\beta$-elemene decreased bcl- 2 expression, increased bax expression and caused the cleavage of PARP. However, $\beta$-elemene also induced the phosphorylation of Akt and ERK in a short period of time. The inhibition of Akt and ERK activation rapidly enhanced $\beta$-elemene-induced apoptosis, and the up-regulation of $\mathrm{c}-\mathrm{Cbl}$ and $\mathrm{Cbl}-\mathrm{b}$ expression was also detected. These results suggest that Cbl-regulated Akt and ERK signals are involved in $\beta$-elemene-induced cell apoptosis in lung cancer cells.
\end{abstract}

\section{Introduction}

Lung cancer is one of the leading causes of cancer-related death in China, and the 5-year relative survival rate of lung cancer patients is only $15 \%$ (1). Chemotherapy achieves a response rate of $20-50 \%$ in advanced non-small cell lung cancer (NSCLC) cases. Although it provides useful palliation, advanced lung cancer remains incurable. Resistance to standard chemotherapy is a common clinical problem that requires novel strategies to enhance the antitumorigenic effects of

Correspondence to: Dr Xuejun Hu, Department of Respiratory Medicine, The First Hospital of China Medical University, Shenyang 110001, P.R. China

E-mail: cmuhuxuejun@yahoo.cn

Dr Yunpeng Liu, Department of Medical Oncology, The First Hospital of China Medical University, Shenyang 110001, P.R. China E-mail: cmuliuyunpeng@yahoo.cn

*Contributed equally

Key words: $\beta$-elemene, apoptosis, Akt, ERK, Cbl chemotherapeutic agents. Many anticancer agents, including bufalin and Taxol, have been isolated from natural products and are used for the treatment of cancer $(2,3)$. Elemene (1-methyl-1-vinyl-2,4-diisopropenyl-cyclohexane), the active component of the traditional Chinese medicinal herb Rhizoma zedoariae, contains $\alpha-, \beta$ - and $\delta$-elemene. It has been reported that $\beta$-elemene effectively treats various carcinomas, such as glioblastoma, and lung and ovarian carcinomas, and recent studies have shown that $\beta$-elemene triggers apoptosis through the down-regulation of Bcl-2 and Bcl-XL (4-7). Whether another signaling pathway is involved in $\beta$-elemene-induced apoptosis in lung cancer cells has yet to be determined.

Several drugs have been reported to stimulate a variety of tyrosine kinase receptors, leading to a rapid elevation in the enzymatic activity of serine-threonine kinases, known as MAP kinases. Extracellular signal-regulated kinases (ERKs) are members of the mitogen-activated protein kinase superfamily that functions in response to DNA damage $(8,9)$. Additionally, the constitutively active Akt, the central mediator of the PI3K pathway, contributes to cell survival and therapeutic resistance in cancer cells $(10,11)$. However, whether $\beta$-elemene-induced apoptosis is accompanied by an alteration in the survival pathway has yet to be determined.

c-Cbl and Cbl-b are members of the Cbl protein family and negatively regulate cellular viability by interacting with Fyn, Grb2, Lck or p85 $(12,13)$. Studies have shown that Cbl protein binding to the p85 subunit of PI3K induces the ubiquitination of the $\mathrm{p} 85$ subunit and the inactivation of the PI3K/Akt pathway $(14,15)$. Our previous study showed that the up-regulation of Cbl-b reduced ERK activition in gastric cancer and leukemia cells (16). However, whether c-Cbl and Cbl-b are involved in $\beta$-elemene-induced apoptosis in lung cancer cells has not been elucidated.

In the present study, $\beta$-elemene induced cell apoptosis together with transient activation of Akt and ERK. The up-regulation of c-Cbl and Cbl-b was also detected. The inhibition of Akt and ERK signals enhanced $\beta$-elemene-induced apoptosis in lung cancer cells.

\section{Materials and methods}

Reagents and antibodies. $\beta$-elemene was purchased from Holley Kingkong Pharmaceutical Co., Ltd. (Dalian, China). 


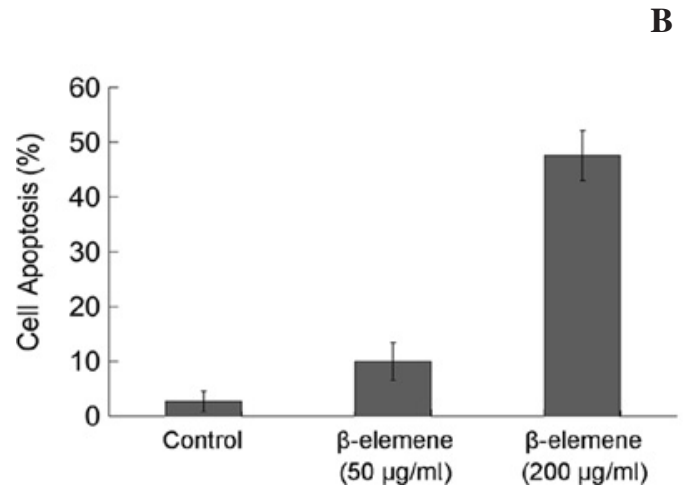

B

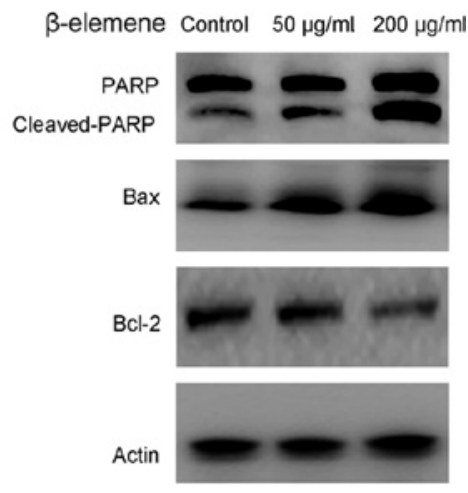

Figure 1. $\beta$-elemene induces cell apoptosis in A549 cells. (A) A549 cells were treated with 50 and $200 \mu \mathrm{g} / \mathrm{ml} \beta$-elemene for $24 \mathrm{~h}$. Cell apoptosis was quantified using flow cytometry. (B) The expression of PARP, bax and bcl-2 was detected by Western blotting.

Anti-bax, anti-bcl-2 and anti-Cbl-b antibodies were purchased from Santa Cruz Biotechnology (Santa Cruz, CA, USA). Antiphospho-Akt, anti-phospho-ERK, anti-Akt and anti-ERK antibodies were obtained from Cell Signaling Technology (Beverly, MA, USA). Anti-c-Cbl antibody was purchased from Transduction Laboratories (Lexington, KY, USA). LY294002 was from Sigma-Aldrich (St. Louis, MO, USA). PD98059 was purchased from Promega (Madison, WI, USA).

Cell culture. A549 human NSCLC cells were obtained from the Type Culture Collection of the Chinese Academy of Sciences. Cell culture was carried out in RPMI-1640 medium containing $10 \%$ fetal bovine serum (FBS), penicillin $(5 \mathrm{U} / \mathrm{ml})$ and streptomycin $(50 \mathrm{mg} / \mathrm{ml})$ in a $95 \%$ air $/ 5 \% \mathrm{CO}_{2}$ atmosphere.

MTT assay. A549 cells were plated in 96-well flat bottom plates and treated with different concentrations of $\beta$-elemene for the indicated times. The cells were then incubated with $20 \mu \mathrm{l}$ of MTT $(5 \mathrm{mg} / \mathrm{ml})$ for $4 \mathrm{~h}$ at $37^{\circ} \mathrm{C}$ and $200 \mu 1$ of DMSO were added to solubilize the crystals for $20 \mathrm{~min}$ at room temperature. The optical density was determined with a spectrophotometer (Bio-Rad, Hercules, CA, USA) at a wavelength of $570 \mathrm{~nm}$. Four replicate wells were measured for each group and each experiment was repeated three times. The median inhibitory concentration $\left(\mathrm{IC}_{50}\right)$ values were determined using the CurveExpert 1.3 software and plotted in dose-response curves.

Flow cytometric analysis. A549 cells were treated with different concentrations of $\beta$-elemene for the indicated times. Then, cells were harvested and fixed with $70 \%$ ethanol at $4^{\circ} \mathrm{C}$ overnight. The cells were incubated in $0.5 \mathrm{ml}$ phosphatebuffered saline (PBS) containing $10 \mu 1$ RNaseA $(0.2 \mathrm{mg} / \mathrm{ml})$ at $37^{\circ} \mathrm{C}$ for $30 \mathrm{~min}$ and then stained with propidium iodide (PI) dye. Finally, the samples were evaluated by flow cytometry and the data were analyzed using WinMDI software.

Western blot analysis. A549 cells were washed twice with icecold PBS and solubilized in $1 \%$ Triton lysis buffer [1\% Triton $\mathrm{X}-100,50 \mathrm{mM}$ Tris- $\mathrm{HCl}$ (pH 7.4), $150 \mathrm{mM} \mathrm{NaCl}, 10 \mathrm{mM}$ EDTA, $100 \mathrm{mM} \mathrm{NaF}, 1 \mathrm{mM} \mathrm{Na} \mathrm{VO}_{4}, 1 \mathrm{mM}$ PMSF and $2 \mu \mathrm{g} /$ $\mathrm{ml}$ aprotinin] on ice. The amount of protein was quantified using the Lowry method. Total proteins $(40 \mu \mathrm{g})$ were subjected to sodium dodecyl sulfate-polyacrylamide gel eletrophoresis (SDS-PAGE) and transferred to nitrocellulose membranes

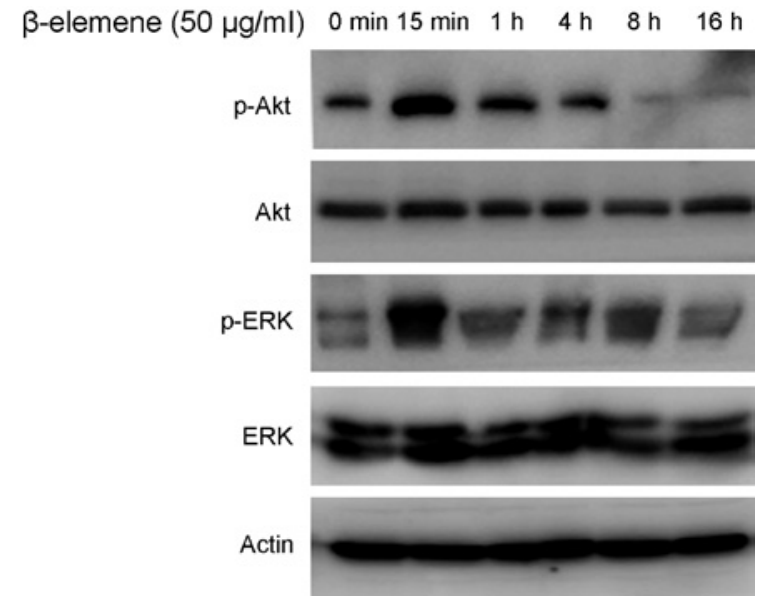

Figure 2. $\beta$-elemene induces the activation of Akt and ERK. A549 cells were treated with $50 \mu \mathrm{g} / \mathrm{ml} \beta$-elemene for $15 \mathrm{~min}, 1,4,8$ and $16 \mathrm{~h}$. The phosphorylation of Akt and ERK was detected by Western blotting.

(Immoblin-P, Millipore, Bedford, MA, USA). Membranes were blocked with $5 \%$ skimmed milk in TBST $(10 \mathrm{mM}$ Tris, pH 7.4, $150 \mathrm{mM} \mathrm{NaCl}$ and $0.1 \%$ Tween-20) at room temperature for $2 \mathrm{~h}$ and incubated with the indicated primary antibodies at $4^{\circ} \mathrm{C}$ overnight. After washing with TBST, the membrane was reacted with the appropriate horseradish peroxidase-conjugated secondary antibody, as indicated, for $30 \mathrm{~min}$ at room temperature. Finally, proteins were visualized using the enhanced chemiluminescence reagent (SuperSignal Western Pico Chemiluminescent Substrate; Pierce, Rockford, IL, USA).

Statistical analysis. Data are expressed as the means \pm SD. Differences between the two groups were evaluated by the Student's t-test. $\mathrm{P}<0.05$ was considered to be statistically significant. Analyses were conducted using the SPSS 13.0 software.

\section{Results}

$\beta$-elemene induces cell apoptosis in A549 cells. Lung cancer A549 cells were treated with different concentrations of $\beta$-elemene for $24 \mathrm{~h}$; the $\mathrm{IC}_{50}$ value was $50 \mu \mathrm{g} / \mathrm{ml}$. Hence, A549 cells were treated with 50 and $200 \mu \mathrm{g} / \mathrm{ml}$ for $24 \mathrm{~h}$, and the cell apoptosis rate increased to $10.01 \pm 3.43$ and $47.56 \pm 4.57 \%$, 
A
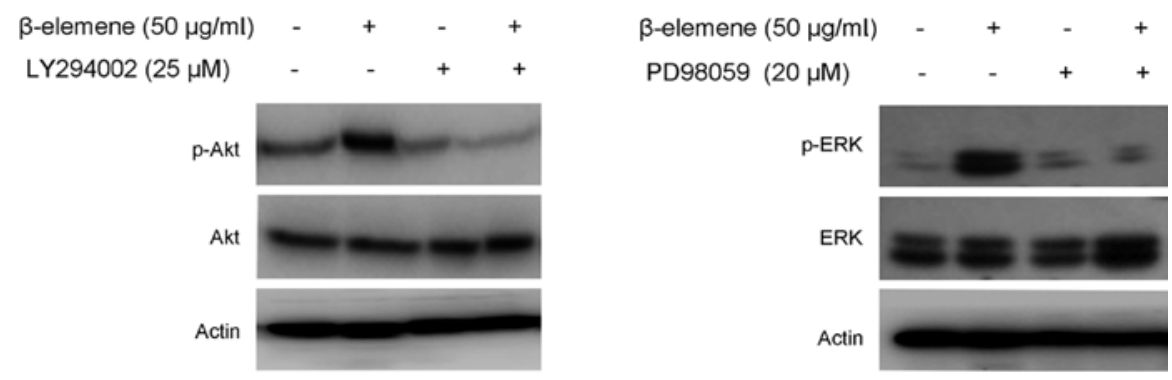

B

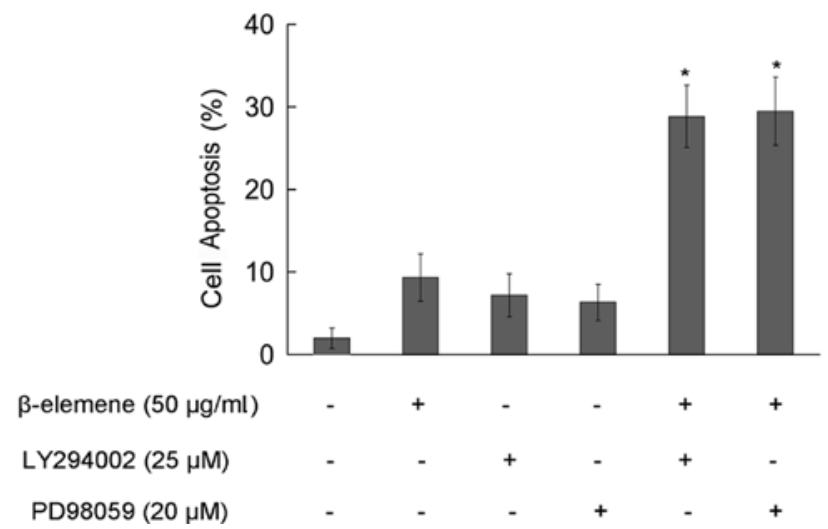

Figure 3. Inhibition of Akt and ERK enhances $\beta$-elemene-induced apoptosis. (A) A549 cells were pre-treated with $25 \mu \mathrm{M}$ LY294002 or $20 \mu \mathrm{M}$ PD98059 for $1 \mathrm{~h}$ followed by $50 \mu \mathrm{g} / \mathrm{ml} \beta$-elemene for $15 \mathrm{~min}$. The phosphorylation of Akt or ERK was detected by Western blotting. (B) A549 cells were pre-treated with $25 \mu \mathrm{M}$ LY294002 or $20 \mu \mathrm{M}$ PD98059 for $1 \mathrm{~h}$ followed by $50 \mu \mathrm{g} / \mathrm{ml} \beta$-elemene for $24 \mathrm{~h}$. Cell apoptosis was quantified using flow cytometry. * Compared to $\beta$-elemene alone, $\mathrm{P}<0.05$.

respectively (Fig. 1A). With the increase in the concentration of $\beta$-elemene, bcl-2 expression was down-regulated, whereas bax expression was significantly up-regulated at $24 \mathrm{~h}$, and the cleavage of PARP was detected (Fig. 1B). These results suggest that $\beta$-elemene-induced apoptosis may be through the mitochondrion-dependent apoptotic pathway in A549 cells.

$\beta$-elemene induces transient activation of Akt and ERK. To determine whether the Akt and ERK signaling pathway is involved in $\beta$-elemene-induced apoptosis, A549 cells were treated with $50 \mu \mathrm{g} / \mathrm{ml} \beta$-elemene for $15 \mathrm{~min}$, at $1,4,8$ and $16 \mathrm{~h}$. As shown in Fig. 2, $50 \mu \mathrm{g} / \mathrm{ml} \beta$-elemene induced a rapid and transient phosphorylation of both Akt and ERK at $15 \mathrm{~min}$. Then, Akt and ERK activation started to decrease and declined to lower levels at $16 \mathrm{~h}$. These results indicate that $\beta$-elemene induces transient activation of Akt and ERK in A549 cells.

Inhibition of Akt and ERK enhances $\beta$-elemene-induced apoptosis. To further confirm that Akt and ERK activation is involved in $\beta$-elemene-induced apoptosis, $25 \mu \mathrm{M}$ LY294002 (the specific inhibitor of PI3K) and $20 \mu \mathrm{M}$ PD98059 (the specific inhibitor of ERK) were used for further experimentation. Pre-treatment with LY294002 or PD98059 for $1 \mathrm{~h}$ reversed the phosphorylation of Akt and ERK induced by $50 \mu \mathrm{g} / \mathrm{ml}$ of $\beta$-elemene at 15 min (Fig. 3A). LY294002 or PD98059 did not affect the cell apoptosis of A549 cells. Compared to $\beta$-elemene alone, pre-treatment with LY294002 or PD98059 followed by $50 \mu \mathrm{g} / \mathrm{ml}$ of $\beta$-elemene for $24 \mathrm{~h}$ the rate of cell apoptosis reached $28.83 \pm 3.78$ and $29.47 \pm 4.13 \%$, respectively $(\mathrm{P}<0.05)$ (Fig. 3B). Our results showed that the inhibition of Akt and ERK enhanced $\beta$-elemene-induced apoptosis in A549 cells. $\beta$-elemene $(50 \mu \mathrm{g} / \mathrm{ml}) \quad 0 \mathrm{~min} 15 \min 1 \mathrm{~h} \quad 4 \mathrm{~h} \quad 8 \mathrm{~h} \quad 16 \mathrm{~h}$

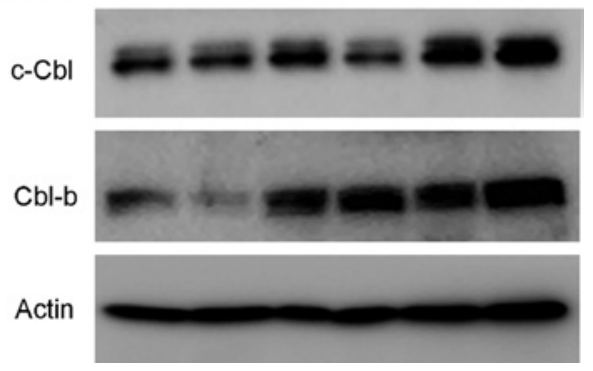

Figure 4. $\beta$-elemene up-regulates the expression of c-Cbl and Cbl-b. A549 cells were treated with $50 \mu \mathrm{g} / \mathrm{ml} \beta$-elemene for $15 \mathrm{~min}, 1,4,8$ and $16 \mathrm{~h}$. The expression of c-Cbl and Cbl-b was detected by Western blotting.

$\beta$-elemene up-regulates the expression of $c$ - $C b l$ and $C b l-b$. To investigate the effect of $c-C b l$ and $\mathrm{Cbl}-\mathrm{b}$ in $\beta$-elemene-induced apoptosis, A549 cells were treated with $50 \mu \mathrm{g} / \mathrm{ml} \beta$-elemene for $15 \mathrm{~min}$, at 1, 4, 8 and $16 \mathrm{~h}$. As shown in Fig. 4, $\beta$-elemene up-regulated the expression of c-Cbl and Cbl-b at $1 \mathrm{~h}$. Both $\mathrm{c}-\mathrm{Cbl}$ and $\mathrm{Cbl}-\mathrm{b}$ protein reached the peak at $16 \mathrm{~h}$. With the up-regulation of c-Cbl and Cbl-b, the phosphorylation of Akt and ERK was reduced (Fig. 2). These results indicate that the $\mathrm{Cbl}$ protein family may be involved in Akt and ERK inactivation in $\beta$-elemene-induced apoptosis of A549 cells.

\section{Discussion}

$\beta$-elemene was found to inhibit cell viability and induce apoptosis in several types of cancer cells (5-7). However, the signaling pathways involved have not been elucidated. It has 
been reported that $\beta$-elemene induces apoptosis by promoting pro-apoptotic-related proteins and down-regulating anti-apoptotic-related proteins, such as Bcl-2 (4). In the present study, $\beta$-elemene induced cell apoptosis in a dose-dependent manner in A549 cells. At the same time, $\beta$-elemene increased bax expression and decreased bcl-2 expression, and finally induced the cleavage of PARP. These results indicate that $\beta$-elemene induces cell apoptosis through the mitochondrion-dependent apoptotic pathway in lung cancer cells.

Recent studies have shown that the activation of Akt and ERK saves cancer cells from drug-induced DNA damage resulting in drug resistance (16-18). In the present study, Akt and ERK were transiently activated at $15 \mathrm{~min}$ after treatment and then depressed by $50 \mu \mathrm{g} / \mathrm{ml}$ of $\beta$-elemene. In addition, the PI3K inhibitor LY294002 or ERK inhibitor PD98059 reversed the activation of Akt or ERK induced by $\beta$-elemene, and finally increased the sensitivity of $\beta$-elemene in the A549 cells. Our results suggest that the inhibition of the survival pathway increased $\beta$-elemene sensitivity in lung cancer cells.

It is evident that the $\mathrm{Cbl}$ protein family is crucial to the ubiquitination and degradation of many proteins. Thus, certain drugs that enhance the activity of the Cbl protein family may provide new strategies for cancer therapy (19-21). Our previous studies found that up-regulation of Cbl-b inhibited Akt and ERK activation, and thus increased the sensitivity of different drugs in gastric cancer and leukemia cells $(22,23)$. In the present study, $\beta$-elemene up-regulated the expression of $\mathrm{c}-\mathrm{Cbl}$ and Cbl-b. During this process, the activation of Akt and ERK was also inhibited. These results indicate that the $\mathrm{Cbl}$ protein family is involved in $\beta$-elemene-induced apoptosis probably via regulation of Akt and ERK activation.

Taken together, our results show that $\beta$-elemene induces apoptosis by delivering apoptotic signals, and Cbl-regulated Akt and ERK signals are involved in $\beta$-elemene-induced apoptosis of lung cancer cells. Our study is important for understanding the clinical applications of $\beta$-elemene in lung cancer.

\section{Acknowledgements}

This study was supported by the Specialized Research Fund for the Doctoral Program of Higher Education (no. 20102104120008), the Fund of the Education Department of Liaoning Province (no. 20060992), and the Fund for Scientific Research of The First Hospital of China Medical University (no. fsfh1003).

\section{References}

1. Edwards BK, Brown ML, Wingo PA, et al: Annual report to the nation on the status of cancer, 1975-2002, featuring population-based trends in cancer treatment. J Natl Cancer Inst 97: $1407-1427,2005$

2. Amano Y, Cho Y, Matsunawa M, et al: Increased nuclear expression and transactivation of vitamin $\mathrm{D}$ receptor by the cardiotonic steroid bufalin in human myeloid leukemia cells. J Steroid Biochem Mol Biol 114: 144-151, 2009.
3. Bacus SS, Gudkov AV, Lowe M, et al: Taxol-induced apoptosis depends on MAP kinase pathways (ERK and p38) and is independent of p53. Oncogene 20: 147-155, 2001.

4. Yao YQ, Ding X, Jia YC, et al: Anti-tumor effect of beta-elemene in glioblastoma cells depends on p38 MAPK activation. Cancer Lett 264: 127-134, 2008.

5. Zhao J, Li QQ, Zou B, et al: In vitro combination characterization of the new anticancer plant drug $\beta$-elemene with taxanes against human lung carcinoma. Int J Oncol 31: 241-252, 2007.

6. Li QQ, Wang G, Zhang M, et al: $\beta$-elemene, a novel plant-derived antineoplastic agent, increases cisplatin chemosensitivity of lung tumor cells by triggering apoptosis. Oncol Rep 22: 161-170, 2009.

7. Li X, Wang G, Zhao J, et al: Antiproliferative effect of betaelemene in chemoresistant ovarian carcinoma cells is mediated through arrest of the cell cycle at the G2-M phase. Cell Mol Life Sci 62: 894-904, 2005.

8. Roberts PJ and Der CJ: Targeting the Raf-MEK-ERK mitogenactivated protein kinase cascade for the treatment of cancer. Oncogene 26: 3291-3310, 2007

9. Tang D, Wu D, Hirao A, et al: ERK activation mediates cell cycle arrest and apoptosis after DNA damage independently of p53. J Biol Chem 277: 12710-12717, 2002.

10. Markman B, Atzori F, Pérez-García J, et al: Status of PI3K inhibition and biomarker development in cancer therapeutics. Ann Oncol 21: 683-691, 2010.

11. LoPiccolo J, Granville CA, Gills JJ, et al: Targeting Akt in cancer therapy. Anticancer Drugs 18: 861-874, 2007.

12. Thien CB and Langdon WY: c-Cbl and Cbl-b ubiquitin ligases: substrate diversity and the negative regulation of signalling responses. Biochem J 391: 153-166, 2005.

13. Wang Y, Chang J, Li YC, et al: Shear stress and VEGF activate IKK via the Flk-1/Cbl/Akt signaling pathway. Am J Physiol Heart Circ Physiol 286: H685-H692, 2004.

14. Fang D, Wang HY, Fang N, et al: Cbl-b, a RING-type E3 ubiquitin ligase, targets phosphatidylinositol 3-kinase for ubiquitination in T cells. J Biol Chem 276: 4872-4878, 2001.

15. Orlowski RZ and Kuhn DJ: Proteasome inhibitors in cancer therapy: lessons from the first decade. Clin Cancer Res 14: 1649-1657, 2008

16. Qu X, Zhang Y, Li Y, et al: Ubiquitin ligase Cbl-b sensitizes leukemia and gastric cancer cells to anthracyclines by activating the mitochondrial pathway and modulating Akt and ERK survival signals. FEBS Lett 583: 2255-2262, 2009.

17. Villedieu M, Deslandes E, Duval M, et al: Acquisition of chemoresistance following discontinuous exposures to cisplatin is associated in ovarian carcinoma cells with progressive alteration of FAK, ERK and p38 activation in response to treatment. Gynecol Oncol 101: 507-519, 2006.

18. Golding SE, Morgan RN, Adams BR, et al: Pro-survival AKT and ERK signaling from EGFR and mutant EGFRvIII enhances DNA double-strand break repair in human glioma cells. Cancer Biol Ther 8: 730-738, 2009.

19. Ettenberg SA, Magnifico A, Cuello M, et al: Cbl-b-dependent coordinated degradation of the epidermal growth factor receptor signaling complex. J Biol Chem 276: 27677-27684, 2001.

20. Thien $\mathrm{CB}$ and Langdon WY: $\mathrm{c}-\mathrm{Cbl}$ and $\mathrm{Cbl}-\mathrm{b}$ ubiquitin ligases: substrate diversity and the negative regulation of signalling responses. Biochem J 391: 153-166, 2005.

21. Qu X, Sada K, Kyo S, et al: Negative regulation of FcRImediated mast cell activation by a ubiquitin-protein ligase Cbl-b. Blood 103: 1779-1786, 2004.

22. Qu JL, Qu XJ, Qu JL, et al: The role of cbl family of ubiquitin ligases in gastric cancer exosome-induced apoptosis of Jurkat T cells. Acta Oncol 48: 1173-1180, 2009.

23. Li Y, Qu X, Qu J, et al: Arsenic trioxide induces apoptosis and $\mathrm{G} 2 / \mathrm{M}$ phase arrest by inducing $\mathrm{Cbl}$ to inhibit PI3K/Akt signaling and thereby regulate p53 activation. Cancer Lett 284: 208-215, 2009. 